\title{
The Environment Management of Inclusive Schools at Primary Schools
}

\author{
Widya $^{1}$, Rifma $^{2}$ \\ Faculty of Education Science, Universitas Negeri Padang ${ }^{1,2)}$ \\ widia@gmail.com ${ }^{1),}$ rifmar34@fip.unp.ac.id ${ }^{2)}$
}

\begin{abstract}
This Research is aimed at describing the management of inclusive schools which can be used as a reference for principals, teachers and stakeholders in the management of inclusive school environments. This article is the result of a qualitative descriptive study conducted at SDN 33 Payakumbuh. The informants of this study were the school principal, class teacher, special assistant teacher (GPK) and students. Collection techniques use observation, interviews and documentation. Data were analyzed through three pairs namely data reduction, data presentation, and concluding. The results showed that the inclusion of Environmental Management in SDN 33 Payakumbuh was carried out in two aspects, namely physical accessibility and fostering a conducive environment. Both aspects have not been fulfilled optimally by the school. In terms of physical accessibility, it still requires facilities and infrastructure that do not meet the service standards of Children with Special Needs. The results also show facts about the synergy and cooperation of parties ranging from school principals, teachers, administrative staff, students and parents to foster a conducive inclusive school environment. Keywords: Management, Environment, Elementary School, Inclusion
\end{abstract}

\begin{abstract}
Abstrak. Artikel ini, bertujuan untuk mendeskripsikan manajemen lingkungan sekolah inklusi yang dapat dijadikan salah satu rujukan kepala sekolah, guru dan stakeholder dalam mengelolaan lingkungan sekolah inklusif. Artikel ini merupakan hasil penelitian deskriptif kualitatif yang dilaksanakan di SDN 33 Payakumbuh. Informan dalam penelitian ini adalah Kepala sekolah, Guru kelas, Guru pendamping Khusus (GPK) dan siswa. Tehnik pengumpulan menggunakan observasi, wawancara dan dokumentasi. Data dianalisis melalui tiga tahap yaitu reduksi data, penyajian data, dan menarik kesimpulan. Hasil penelitian menunjukkan bahwa Manajemen lingkungan sekolah inklusi di SDN 33 Payakumbuh dilaksanakan dalam dua aspek yakni aksessbilitas fisik dan menumbuhkan iklim yang kondusif. Kedua aspek ini belum terpenuhi oleh sekolah secara optimal. Ditinjau dari aksebilitas fisik masih terdapat sarana dan prasarana yang tidak memenuhi standar pelayanan Anak Berkebutuhan Khusus. Hasil penelitian juga menunjukkan bahwa terdapat sinergi dan kerjasama berbagai pihak mulai dari kepala sekolah, guru, staf administrasi, siswa dan orang tua untuk menumbuhkan lingkungan sekolah inklusif yang kondusif.
\end{abstract}

Kata Kunci: Manajemen, Lingkungan, Sekolah Dasar, Inklusi 


\section{INTRODUCTION}

Children with special needs or known as ABK are children who have a specialty compared to children in general. Children can be declared special needs if there are weaknesses or strengths in the child. These strengths and weaknesses can be in the form of physical, mental or emotional that make children have special needs (Dedi: 2016). Therefore, $\mathrm{ABK}$ requires a form of special education services that are tailored to the capabilities and potential it has. As stated in Law No. 20 of 2003 concerning the national education system which explains that special education is education for students who have difficulty in participating in the learning process due to physical, emotional, mental, social, and / or potential disabilities and special talents. Realizing this, the government is very serious in handling the field of education, one of which is providing educational services for children with special needs attending education in regular (inclusive) schools.

Inclusive education is an educational service for students with special educational needs in regular schools (elementary, junior high, high school, and vocational school) and is classified as extraordinary both in terms of disabilities, slow learners (slow learners) and learning difficulties (Darma, et al: 2016) . The practice of inclusive education does not only mean incorporating children with special needs into public schools, but inclusive education is a process of participation in all aspects of the school. So, one component of inclusive education is creating a learning environment that is made in such a way that the teaching-learning process can take place safely and comfortably (Khoeriah, 2017). Inclusive education focuses on the interaction of creating a friendly environment for all the needs of students.

The implementation of inclusive education refers to the educational needs of all children (education for all). This is suspected because the implementation of inclusive education requires the management of students. According to Knezevich (Ali Imron, 2011: 6), student management or pupil personnel administration is a service that focuses on the regulation, supervision and service of students in class or outside the class such as: introduction, registration, individual services such as capacity development, interests, needs until students mature in school. Arrangements for students are done to provide the best possible service to students, including students with special needs in the implementation of inclusive education so that each student gets proper education services without discrimination.

Yusmaniar (2017) in her research revealed that ideally the management of inclusive school environments especially in primary schools needs management to run well. School management will be effective and efficient if it is supported by professional human resources to operate the school, a 
curriculum that is in accordance with the level of development and characteristics of students, ability and task commitment (reliable responsibility for the teaching staff), adequate infrastructure to support activities teaching and learning, sufficient funds to pay staff according to their functions, as well as high community participation. If one of the things above is not as expected or does not function as it should, the effectiveness and efficiency of school management is not optimal.

This indicates that the management of an inclusive school environment in primary schools should be an education service system that requires that all children with disabilities be served in school, in regular classes with friends who have same age. Inclusive education in schools which is shown as an integrated inclusion organizer through policies, culture, and practice of learning in the classroom. As expressed by Siti, et al (2018) that there is an integrated pattern in the management of inclusive school environments in primary schools, the pattern is formed starting from planning, curriculum, implementation involving all parties, namely the principal to the teachers by including the culture of children so that the children can be accommodated properly. Thus, inclusive education focuses on the interaction of creating an environment that is friendly to all the needs of students. Furthermore, this article is designed to reveal the environmental management of inclusive schools in SDN 33
Payakumbuh city in terms of the aspects of physical accessibility and climate of the incusive school. The results of this study are expected to be able to contribute to the world of education especially the administration of education and give an idea to the government, the community that moves and explore the world of education in particular, related to the management of inclusive school environment in elementary schools.

\section{RESEARCH METHODS}

This article was descriptive qualitative research to describe a complete and complete phenomenon. Qualitative research was chosen to reveal and describe facts from a certain perspective (Burhan Bungin, 2007). The research location was SDN 33 Payakumbuh, the research informants were the Principal, Classroom Teacher, Special Assistant Teacher (GPK), Administrative Staff, Parents. Research procedures started from collecting data, organizing data, analyzing data. While data collection techniques in this study were observation, interviews, and documentation. Analysis of the data in this study were (a) Data collection in this study was carried out in various ways such as observation, interviews and documentation. Data collected were objective and following existing challenges in the field Data collected on school physical accessibility and conservation of inclusive schools (b) Data reduction, the data obtained by researchers were selected which were 
important and which did not need to be used in this study. (c) Presentation of data obtained from data reduction, the data then presented and compared with the theory that had been made, (d) drawing conclusions and verification that could answer the focus of the problem or the formulation of the problem in this study.

\section{DISCUSSION}

Management is a work activity that involves coordination and supervision of the work of others so that the work can be completed efficiently and effectively (Stefan: 2010). School management gives full authority to the principal to plan, organize, direct, coordinate, supervise, and evaluate the educational components of a school that includes student input, education personnel, infrastructure, funds, management, environment, and teaching and learning activities. Management includes activities to achieve goals, carried out by people who dedicate their best efforts through a predetermined action. This includes knowledge, about what needs to be done, applying methods of how to do it, understanding how to do it and measuring the effectiveness of those efforts. Management is a process of completing activities efficiently with or through others and related to the routine tasks of an organization. The combination of strong management and leadership will produce a high output.
Leadership will succeed if supported by strong management skills. Management will be strong and able to develop organizations if can be done by a strong leader.

In education, besides the importance of management, education is a means to develop the dimensions of human nature as a whole, namely as integrated coaching of the dimensions of human nature so that it can grow and develop in harmony (Umar). Education that is able to accommodate various backgrounds of students is what is called inclusive education. Educational services for exceptional children undergo many changes. These changes in education for exceptional children include changes in awareness and attitudes, circumstances, methodology, use of related concepts and so on. Educational services for exceptional children continue to develop so that exceptional children get the same rights as children in general in education. Inclusive education Environmental Management which is the latest development of a model for exceptional children is formally implemented. Nowadays, educational institutions are starting to realize that there are full and comprehensive educational needs through inclusive education starting at the elementary school level.

In this case, the research findings show that the management of an inclusive school environment in primary schools is carried out through the following stages:

1. Planning 
Planning in the management of the inclusive school environment at SDN 33 Payakumbuh with physical accessibility conducted by the school by mapping the facilities and infrastructures needed by students and special needs students. The results of school mapping in fulfilling facilities and infrastructures show that schools need Ram or ramps. This ram should be provided at each entrance so that it is easily accessible, both for wheelchair users and people with visual impairments. Then the need for a Guilding Block to make it easier for the visually impaired to walk to the facility or building you want to go. While in the case of a conducive school climate, schools plan together through teacher meetings, committees, etc. Sound warnings (visually impaired) or lamp warnings (for the hearing impaired), or sound and lamp warnings for all students. The school has a special room/resource room. Schools have media, special tools needed in the learning of children with special needs (Elisa; 2013).

\section{Organizing}

Organizing is carried out with the task division model. There is someone who is appointed as the person in charge of implementing inclusive education, who is carrying out their duties is assisted by class teachers, subject teachers and accompanying teachers, the inclusive education coordinator conducts inclusive education and overcomes the abilities and shortcomings of students with special needs.

\section{Instruction}

A direction which is to provide motivation and leadership. Principals as leaders give motivation to their subordinates to do inclusive education. The tendency for direction is more emphasized to the class teacher and homeroom teacher as the main actors in inclusive education.

\section{Evaluation}

Evaluation can be carried out with a control and supervision system for inclusive education which is conducted every three months. This monitoring is also carried out by sharing the results of evaluations of students with special needs that will be conveyed to the guardians of students. In addition, each month each school held a monthly meeting as a way of direction and control. Evaluation of environmental management of inclusive schools in SDN 33 Payakumbuh is done to assess whether all activities that have been carried out have achieved the objectives set. Evaluations must be flexible to know what is already there, what has been done, what hasn't been done, and what hasn't been done in implementing inclusive education programs in each education unit. It is hoped that monitoring and evaluation can be used as material for selfimprovement and guidance from related parties in developing inclusive education better. Monitoring and evaluation of the implementation of inclusive education is 
carried out in an integrated manner by involving principals, school committees, education offices, and other parties related to the implementation of activities.

Based on the inclusion school environmental management stages above, the research findings also show problems that arise in the management of inclusive school environments in Payakumbuh City elementary schools. These problems start from problems related to teachers who complain that teachers lack competency in handling ABK. This is due to the lack of teachers' understanding of ABK and inclusive schools which then has an impact on the problems that arise next, namely the difficulty of teachers in teaching and learning activities because of the lack of supporting facilities and class structuring that is still classified as not yet in accordance with the physical accessibility standards of inclusive schools. Abwatie (2017) states that in the accessibility component there are points that measure the extent of the school's efforts in providing facilities for the provision of education for children with special needs from building problems and school layout that are adapted to children with special needs.

Another thing that is found is that $\mathrm{ABK}$ has a high dependence on other people including teachers ranging from learning problems but also administrative issues. This condition reveals the fact that class teachers do not have the full capacity to carry out in full thus require the presence of Special Assistant
Teachers. Because the workload of teachers increases with $\mathrm{ABK}$ administrative issues indirectly impacting on how teachers handle students, especially ABK in schools, is not optimal.

Furthermore, the results of the study also show that various problems that arise related to the management of inclusive schools in terms of teachers, students, parents, schools, communities, government, facilities and infrastructure are lacking, and lack of cooperation from various parties so that the impact is less than the maximum implementation of inclusive schools. This is in accordance with what Sunaryo (2007) stated that for the success of inclusive schools, it needs to involve many parties. Bines (in Carrington and Robinson, 2004) suggested that inclusive schools are a process that involves all school staff and students for their development such as how to approach student organizing, the role of teaching staff.

This was also stated by Giangreco (2013) schools must also work with the school community such as teachers, class assistant teachers, parents, students, school administrative teams, and school communities to maximize teacher performance. This condition shows that actually schools can also develop the improved quality of inclusive schools through teachers and related parties and synergize every element of the school starting from teachers, students, administrative staff, assistant teachers and parents. According 
to Siver in Komariah and Triatna (Hamzah: 2016), the social climate of a school is formed by the reciprocal relationship between the behaviour of School leaders and the behaviour of teachers as a group. The behaviour of school leaders can influence the interpersonal interactions of teachers. Thus the dynamics of leadership undertaken by school leaders and groups (teachers and staff) are seen as key to understanding variations in the school climate. SDN 33 Payakumbuh has done through collaboration between teachers and teachers, teachers with accompanying teachers, administrative staff, students and special needs students.

Regarding this situation, the emergence of problems related to the management of inclusive school environments in primary schools was also triggered by the lack of infrastructure to support the implementation of inclusive schools and the lack of cooperation from various parties. Shows that teachers are a major factor in the process of inclusive education, but without the help of other parties the implementation of inclusive schools cannot run optimally so that besides the teachers handled, it is also necessary to foster a culture of inclusive schools both within the school itself or the community outside the school, besides, government policies also determine the implementation of inclusive schools.

\section{CONCLUSION}

The management of an inclusive school environment in SDN 33 Payakumbuh is viewed from two aspects namely the aspect of physical accessibility and the development of a conducive school climate. Both of these aspects become urgent in supporting the needs of students, especially $\mathrm{ABK}$ students in the learning process in the school environment. Therefore, these two aspects must be fulfilled optimally. Related to the management of an inclusive school environment in SDN 33 Payakumbuh, the school principal has sought the implementation of the program that has been prepared. This can be known through program planning, program implementation, and program supervision activities carried out by the school principal and the local education office. Supervision is carried out to determine the extent to which this inclusive education program runs in the classroom (curriculum, facilities and infrastructure of learning and special assistant teachers), and also to provide an assessment of both what has been achieved and what has not yet been achieved. However, in its implementation, the management of the inclusive school environment in primary schools encountered many problems, namely school facilities that were not yet friendly to inclusion students and the acceptance of other children to include students and the lack of teacher coordination in the management of inclusive elementary schools. 


\section{REFERENCES}

[1] A.K. Mudjito, Harizal, dan Elfindri. (2012). Pendidikan Inklusi. Jakarta: Baduose

[2] Amtu, Onisimus. (2011). Manajemen Pendidikan di Era Otonomi Daera. Bandung: Alfabeta

[3] Arnada, Hega Raka. (2014). Manajemen Peserta Didik Sekolah Inklusif di Sekolah Menengah Pertama PGRI Kecamatan Kasihan. UNY. Skripsi tidak diterbitkan. Yogyakarta: PPs Universitas Negeri Yogyakarta.

[4] Benninga, J. S., Berkowitz, M. W., Kuehn, P., \& Smith, K. (2006). "Character and academics: what good schools do.Phi Delta Kappan."Sage Journal.Diakses pada 4/11/2014

http://pdk.sagepub.com/content/87/6/448.sho

$\underline{\mathrm{rt}}$

[5] Bungin, Burhan, (2009), Metodologi Penelitian Kuantitatfi,cet. Ke-4 Jakarta: Kencana Prenada Media Group.

[6] Daniela Dimitrova, Radojichich, Natasha Chichovska, Jovanova. (2014). Parents Attitude: Inclusive Education of Children with Disability. International Journal of Cognitive Research in Science, Engineering and Education. Vol. 2 (1): hal. 16.

[7] Forlin, Dianne Chambers, Tim Loreman, Joanne Deppeler, and Umesh Sharma. (2013). Inclusive Education for Students with Disability. A Review of The Best Evidence in Relation Theory and Pracitce. Australia:ARACY.

[8] Garnida, Dadang. (2015). Pengantar Pendidikan Inklusif. Bandung: Refika Aditama.

[9] Glazzard Jonathan, Jane Stokoe, Alison Hughes, Annatte Netherwood,and Lesley Neve. (2016). Teaching and Supporting Children with Special Education Needs and Disabilities in Primary School. Sage Publication:London

[10] Hallahan, Daniel P. dan James M. Kauffman. (1988). Exceptional Children: Introduction to Special Education, 4th ed. New Jersey: Prentice-Hall.
[11] Hamza B. Uno. (2016) Landasan pendidikan. (akarta: PT Bumi Aksara.

[12] Ilahi, Muhammad Takdir. (2013). Pendidikan Inklusif (Konsep dan Aplikasi). Jogjakarta: Ar-Ruzz Media.

[13] Irwanto, NurdanSuryana, Yusuf. (2016). KompetesiPedagogik. Surabaya: Genta Group Production.

[14] Karwati, Euis, Priansa DonniJuni. (2014). Manajemen Kelas (Classroom Management). Bandung: Penerbit Alfabeta.

[15] Lembaga Pengembangan Sarana Pengukuran dan Pendidikan Psikologi (LPSP3) Kampus Baru UI, Depok. Media

[16] Mangunsong, F. (2009). Psikologi dan Pendidikan Anak Berkebutuhan Khusus Jilid I. Jakarta.

[17] McLoughlin, James. A, and Lewis, Rena. B. (2013). Assesing Special Students. Columbus: Charles E. Merrill Publishing Company.

[18] Miles, Metthew B, A, et al. (2014). Qualitative Data Analysis, A Methods Sourcebook. Thitd Edition. United States of America: Sage Publications, Inc.

[19] Mudjito, dkk. (2012). Pendidikan Inklusif. Jakarta: Banduose Media.

[20] Osberg, D., \& Biesta, G. (2010). The end/s of education: Complexity and the conundrum of the inclusive educational curriculum. International Journal of Inclusive Education. Vol. 14(6): hal. 593-607.

[21] Robyn Robinson, Suzanne Carrington. (2002). Professional Development for Inclusive Scooling. The International Journal of Educational Management. Vol 16 (5) 239 247.

[22] Rosaini. (2016). Pengembangan Bahan Ajar Menggunakan Model Circuit Learning Berbasis PMRI Pada Pembelajaran Sistem Persamaan Lenear Dua Variabel Kelas VIII Semester 1. Tesis tidak diterbitkan. Yogyakarta:PPS Universitas Negeri Yogyakarta. 
[23] Sagala, Syaiful, (2006). Administrasi Pendidikan Kontemporer, Cet ke-3, Bandung : Alfabeta,

[24] Sagala, Syaiful. Manajemen Strategik dalam Peningkatan Mutu Pendidikan. (2009). Bandung: Alfabeta.

[25] Santrock, J.W. (2014). Psikologi Pendidikan. Edisi 5 Buku 2. Terjemahan: Harya Bhimasena. Jakarta: Salemba Humanika

[26] Sharma, U., Forlin, C., Deppeler, J., \& Guang-xue, Y. (2013). Reforming teacher education for inclusion in developing countries in the Asia Pacific Region. Asian Journal of Inclusive Education. Vol. 1 (1): hal. 3.

[27] Tarmansyah. (2007). Inklusi Pendidikan untuk Semua.Jakarta: Depdiknas 